\title{
Framing in a contested space: Media reporting on tourism and mining in Australia
}

Dr Char-lee J. McLennan ${ }^{\mathrm{a}}$

Professor Susanne Becken ${ }^{\mathrm{a}}$

Dr Brent D. Moyle

${ }^{a}$ Griffith Institute for Tourism, Griffith University

${ }^{b}$ School of Tourism and Hospitality Management, Southern Cross University

Accepted for publication in Current Issues in Tourism. 


\title{
Framing in a contested space: Media reporting on tourism and
}

\section{mining in Australia}

\begin{abstract}
The last decade has seen Australia's economy undertake a significant transformation, with a rapid resurgence in mining. The high exchange rate that has arisen as a consequence of this boom has resulted in a number of other Australian industries becoming less competitive, leading to a two-speed economy. For the tourism industry the result has been declining visitation, with some commentators attributing this decline directly to the mining boom. This paper explores how the media frames tourism- and mining-related issues regarding the current mining boom in Australia by undertaking a content analysis of 265 online newspaper articles relating to tourism and mining in Australia. The impact of mining on the tourism sector was frequently identified as a key issue, with the rapid expansion of mining increasing competition for labour, resources and infrastructure, as well as having the propensity to destroy certain tourism products. Journalistic techniques, such as hedging, were found to be prevalent in the media reporting, potentially leading to confusion surrounding key issues relating to tourism and mining in the public forum. Future research should seek to explore strategies that could be used by government and businesses to build sustainable, resilient regions through tourism and mining.
\end{abstract}

Keywords: Tourism, Mining, conflict, media, framing, hedging 


\section{Framing in a contested space: Media reporting on tourism and}

\section{mining in Australia}

\section{Introduction}

The tourism and mining sectors have both been identified as instigators of significant structural change in economy and society (Battellino, 2010; McLennan, Ruhanen, Ritchie \& Pham, 2012), each accompanied by their own social, cultural and environmental challenges (Connolly \& Lewis, 2010). The relationship between tourism and mining is complex, and conflict between these two sectors is not uncommon, especially when economic values compete with other values held by multiple stakeholders (Wergin \& Muecke, 2012). More indepth analyses of the relationship between tourism and mining, and public perceptions of the interaction between the two industries, is needed to better understand the nature of the relationship, the complexity of the conflict, the public debate around it and the values embedded in the various viewpoints taken to assess the relationship.

The media plays a key role in the social representation of the relationship between mining and tourism and can significantly influence public opinion and shape policy agendas (Hurlimann \& Dolnicar, 2012). For example, at the time of the Victorian Gold Rush in Australia (circa 1851 to late 1860 s), the media played a critical role in influencing events, forming public opinion and developing community identity (Hughes, 2003; Morrison 1980). An understanding of the media representation of current mining and tourism issues is a critical first step in understanding whether there may be gaps between the perception and reality of key issues, particularly in regards to the implementation of policies by potentially out-of-touch decision-makers. 
As a result, this paper aims to understand how the media frames tourism- and miningrelated issues regarding the current mining boom in Australia by undertaking a media analysis of 265 online newspaper articles relating to tourism and mining in Australia published between January 2012 and January 2013. Broadly, this study seeks to understand how two industries, in this case tourism and mining, are framed in the media in a competitive context. The findings inform a more general model of media effects in relation to complex relationships that are discussed by journalists. In addition, the analysis seeks to explore whether the discourse surrounding mining and tourism may be confusing the audience (who are the public, as well as policy-makers) and in turn increasing the difficulty with which clear policies can be set.

\section{The competitive context between mining and tourism}

The literature provides some evidence of resident perceptions of tourism and mining, and the relationship between them (Moyle, McLennan, Becken \& Brown, 2014). A prominent issue seems to be that mining is perceived to destroy the environmental or cultural product that tourism is often based upon (Lichrou \& O’Malley, 2006). Considering that almost a third of mining and exploration sites are located in areas of intact ecosystems or conservation areas worldwide (Miranda et al., 2003), which are often tourism products, this is an important issue. Indeed, Huang (2008) concludes that the two industries generally perform better economically when they are separate.

However, the relationship between tourism and mining is not necessarily a negative one. For instance, Buultjens et al. (2010) argue that it is possible for tourism and mining to cluster together, with tourism seeking advantages from increased infrastructure and government tax revenues in mining areas. The mining sector can also actively participate in tourism by providing access to industrial, mining-related tourist attractions (Moyle et al., 
2014). Numerous examples exist, especially in Europe, where former mining sites have turned into major mining heritage tourism products (Ballesteros \& Ramirez, 2007) and in Australia where the resources sector is currently funding mining tours in Gladstone (Moyle et al., 2014). Wergin and Muecke (2012), however, remind us that the social representation of mining through a tourist activity is not necessarily free of challenges, especially when tourist ventures reinforce colonialist myths at the expense of representing the full extent of injustice done to local, and often indigenous, communities in the exploration and exploitation process.

Australia is an excellent example of how a booming mining sector interacts with tourism. Australia has witnessed four previous mining booms over the last 150 years (identified by Battellino (2010), these are: the 1850 s gold rush, the late $19^{\text {th }}$ century mineral boom, the 1960s/early 1970s mineral and energy boom, and the late 1970s/early 1980s energy boom), which no doubt have shaped public perceptions of mining. However, it is the current mining boom, which has taken hold since the turn of the current century, that is of particular importance (Measham, McKenzie, Moffat \& Franks, 2013). This is due to mining's significant role in the overall economy (representing 8\% of GDP and employing 144,000 Australians; Australian Bureau of Statistics, 2012), the improved technology that allows increased extraction of resources without increasing labour input, and the impacts on a fully floated exchange rate (Battelino, 2010). Indeed, the current mining boom has had a massive influence on the Australian economy, both negative and positive (Richardson \& Denniss, 2011), driving trade balances, gross domestic product and interest, inflation and investment rates (Cleary, 2011; Peck, 2013).

The current mining boom has seen industries, like tourism, struggle under a high exchange rate and strong competition for labour amongst other factors, which has made them less competitive resulting in the emergence of a 'two-speed' economy (Tourism Research Australia, 2013). Some commentators attribute this effect to the so called 'Dutch disease' 
(Prior, Giurco, Mudd, Mason \& Behrisch, 2012; Forsyth, Dwyer \& Spurr, 2014), which describes the adverse effects that occur when one industry rapidly expands at the expense of other industries in an economy (Nowak \& Sahli, 2007). The issue of a two-speed economy and its social impacts has been frequently noted in regards to resource dependent towns, particularly in a North American context (Leatherman \& Marcouiller, 1996; Markey, Halseth \& Manson, 2008). However, there is relatively little research investigating similar issues in Australia (Tonts, Plummer \& Lawrie, 2012). What research does exist tends to focus on single town or region case studies of resource dependent regions with social issues, with little consideration of broader perspectives or the impact mining has on other industries present in an economy, particularly its interaction with tourism. Understanding the interaction between the resources sector and other industries, such as tourism, is critical as mining in a region is often transitory (Peck, 2013) and having a diversified economy can ensure more resilient regions (Wilson, 2010).

Moreover, it has been argued that the Australian Government has been promoting the current mining boom simply as a generator of revenue and has supported its expansion into new regions solely on this basis (Hughes, 2012). This expansion has often been in places of iconic tourism status intertwined with national identity (e.g. the Great Barrier Reef, Kakadu National Park), protected areas, and indigenous communities and has at times been at the expense of the environment, communities and other sectors (Haalboom, 2012). This raises normative questions of whether supporting mining solely for its economic importance actually increases conflict between mining and other stakeholders, including the community and other industries. Public debate plays a key role in a community's acceptance or opposition to an economic activity, such as tourism and mining (Prior et al., 2012). The way in which the debate is shaped also influences how communities and other stakeholders perceive the activities of different industries and their potential to serve a region in the future. 


\section{Media framing theory}

The effect of media on public perceptions, attitudes and behaviours has been widely discussed by social scientists (Scheufele, 1999). A number of inter-related concepts have been put forward, including agenda setting and framing. While agenda setting refers to what issues or actors are being discussed, framing (or 'second order' agenda setting) relates to how issues are discussed and what schemata of interpretation are employed by the media (Schultz, Kleinnijenhuis, Oegema, Utz \& van Atteveldt, 2012).

Focusing on media framing this research draws on framing theory, which suggests that people use cues, or 'frames', to guide how they understand, think and act on a particular issue (Goffman, 1974, Baran \& Davis, 2009). Thus, people hold individual - or audience - frames when they receive and interpret information. At the same time, framing theory is used to analyse how journalists use so-called media frames to 'package' information (Gamson \& Modigliani, 1989), and wittingly or unwittingly influence people's opinions and the social and political impacts of their reporting (Baran \& Davis, 2009; Hurlimann \& Dolnicar, 2012). Framing involves the selection of certain aspects of an issue to be made more salient in a news article (Entman, 1993). Research relating to framing in communication focuses on the central idea, words, phrases, images and presentation of the information used to construct a news story (Druckman, 2001; Scheufele, 1999). As a result, frames highlight some elements of reality over other elements, thereby biasing individuals' interpretation of the issue (Borah, 2011).

People are often exposed to conflicting frames where they receive different perspectives on an issue and they align with the frame that is consistent with their values (Sniderman \& Theriault, 2004). Regardless, little research has focused on the effects of mixed frame conditions, that is, where opposing or ambivalent frames are presented together (Sniderman \& Theriault, 2004; Borah, 2011) or merge into a new frame. Indeed, Chong and 
Druckman (2007) argue that 'little is known about the dynamics of framing in competitive contexts' (p. 113). In competitive contexts, the opposition frame may be strong enough to shift a person away from their values. Therefore it is important to investigate framing in a competitive context, such as when there is conflict between two industries. As mentioned earlier, research into conflict between tourism and mining is limited and the consideration of the media framing of the relationship between these two industries is one aspect that is critically under-researched.

Framing allows people to develop meaning and interpret issues relating to conflict between tourism and mining and to create an understanding of why the conflict is occurring and how it should be resolved (Gray, 2003). Framing not only influences public opinion, but perhaps more importantly it influences those who make policy decisions (Entman, 2010). It also influences the media system (i.e., journalists, editors, media organisations, board members and opinion leaders); whose individual frames and perceptions are not independent of, or isolated from, the wider effects of mass communication (Scheufele, 1999). The media play a key role through frame building (the pitch of the story) and frame setting (techniques used to communicate the frame) activities.

Druckman (2004) distinguishes between issue framing and valence framing. Issue framing refers to the aspects of the issues that the communication highlights for people to consider, while valence framing refers to the portrayal of the information in either a positive or negative light. A third form of framing, stance framing, has also been recognised, whereby a news article can be framed to either support or not support an issue (stance or position), which can result in a framing effect on readers' judgements (Brewer, Graf \& Willnat, 2003). The valence and stance framing of the article can be investigated by considering either the headline or the entire article (Bacon, 2011). 
Generally, stakeholders on different sides of a conflict have different policy frames and they use these to argue their viewpoint tactically (Nie, 2003), for example by using symbols, such as iconic species or places (Stone, 1989). The media often portrays an 'adversarial frame' in relation to environmental policy issues; that is, where there is often irreconcilable conflict between two opposing groups (Karlberg, 1997). Under such a frame alternative perspectives and possible outcomes are limited with the media report being confined to a 'them versus us' style discussion that devalues the shared values and common ground between stakeholders.

Hedging is a linguistic politeness strategy that journalists use to make a provisional claim about an issue, even though the claim is not yet supported or accepted within the literature or community (Myers, 1989). The use of hedging often indicates that there is a degree of uncertainty surrounding a particular issue that may cause confusion amongst the audience. For example, hedging includes the use of words that soften a claim, such as may, suggest, appear, could, might, can, tentative, most likely, uncertain and seem (Hurliman \& Dolnicar, 2012). Another common strategy employed by journalists is promotional language termed superlativism (Schmallegger \& Carson, 2010). Understanding the use of stance, hedging and superlatives in the context of media reporting on tourism and mining issues is important as it can provide insight into framing and where a reader might be confused or influenced about a certain topic (Hurlimann \& Dolnicar, 2012; Schmallegger \& Carson, 2010), and which perspective is being promoted.

Media analyses have been applied in a wide variety of contexts, including issues surrounding policy and planning (Carson, Schmallegger \& Harwood, 2010), environmental risks (Jönsson, 2011), water (Hurliman \& Dolnicar, 2012), global warming (Dispensa \& Brulle, 2003), health pandemics (Wallis \& Nerlich, 2005) and conflict in natural resource management (Bengston \& Fan, 1999). There is also a substantial body of media analyses in 
the tourism literature including, but not limited to, investigations into weather and climate representations of tourist destinations (Wilson \& Becken, 2011), the strategic role of state government in relation to marketing and development (Schmallegger \& Carson, 2010) and the marketing of tourist destinations (Pan, Tsai \& Lee, 2011). Relevant to competitive contexts, one study by Champion and Chapman (2005) investigated the competing frames of the Australian Hotels Association (AHA) and the tobacco control group in Australian print news when the pub smoking bans were introduced. They found that health advocates' success in implementing smoke-free pubs was due to enduring media advocacy that consistently stated facts and appealed to contemporary Australian and world opinion. Media analyses of mining have been relatively limited, although Zhu and McKenna (2012) investigated the legitimisation of a Chinese takeover of Australia's Rio Tinto, finding that the majority of the discourse was rationalistic strategies that were negative to the takeover, resulting in the bid failing.

However, despite these previous media analyses, there has been little consideration of the media reporting in competitive contexts, particularly in relation to the relationship between tourism and mining in the context of the current mining boom in Australia. Given this, there is a need to investigate the way that content relating to tourism and mining is expressed by the media and to expand current conceptual models of media framing to be application in this competitive context. Based on the media analysis literature, five journalistic writing techniques (issue framing, stance, valence framing, hedging and superlatives) were identified as frame building and setting tools that could guide the analysis of the news stories reporting on the relationship between tourism and mining in Australia. 


\section{Method}

Media analysis was selected as an appropriate tool for gaining a better understanding of the representation and public discourse of tourism and mining. Today the internet plays an integral role in distributing news to the public and is opening up new opportunities for the distribution of print media, with many articles now being published online (Lebert, 2008). Therefore it was considered appropriate to restrict this study to online news articles for ease of access to a representative sample of newspaper articles. However, as a consequence, a limitation of this research is that only freely available online in-print articles were collected, so audio or televised news may be under-represented. However, with many news-providers now publishing transcriptions of their in-print, audio or televised news online, this was not considered to overly bias the data.

The online news articles relating to tourism and mining published between January 2012 and January 2013 were collected over a three-month period in early 2013 . This time period was selected because informal discussions with tourism industry representatives indicated that tourism in Australia was struggling despite a global recovery of tourism since the Global Financial Crisis in 2008/9. The time frame therefore seemed appropriate to capture recent trends in Australian tourism that may be correlated to domestic economic structures rather than global pressures. It is acknowledged that the time frame used for analysis is likely to influence the results as media analyses are distorted by the timing and political climate in which the research is undertaken, with current issues, global events and elections often dominating media reporting. Consequently, one year of data may not necessarily be representative of another year.

Online news articles were selected via keyword searching Google News (https://news.google.com.au/), with the specific search term being 'tourism mining Australia', with the particular order of the search terms being irrelevant. Articles were delimited to 
discussions on tourism and mining in an Australian context. As a result a majority, though not all, of the articles sourced were from Australian media outlets. This narrow search term was important to ensure only highly relevant articles were collected. However, the narrow keyword search used to obtain articles may introduce a bias as additional search terms could have achieved different articles. All online news articles were collected if they satisfied the search term criteria and were published during the in-scope period. Following collection, each article was checked to ensure it discussed both tourism and mining in the Australian context, with about one in four articles being discarded for not being in-scope. Many of these were related to tourism and mining in other countries, often associated with trade relations, with Australia only being mentioned in passing.

Once the final set of 265 in-scope articles were determined, the following information was collected from each article and recorded in a Microsoft Excel database:

- details of the article (title, date and year published, publisher);

- the region discussed (including national and state level);

- discussion relating to tourism and mining (that is, an extract of the relevant sections of the article);

- the stance (pro- or anti- mining/tourism) and valence framing (positive or negative slant) of the article; and,

- the prevalence of hedging and superlativism (in regards to tourism and mining discussions and based on coding of key words identified to be associated with hedging and superlativism)

Content analysis is a common method employed for media analyses and has been previously employed in tourism research (Ruhanen, McLennan \& Moyle, 2013). The media discussions relating to tourism and mining were initially coded into key issues, which were then coded inductively into nine key themes (Maddison \& Watts, 2011), in order to identify 
issue framing. Following Newman (2012), open, axial and selective coding was used to draw out key themes from the data. Open coding involved an initial examination of the media content. During this stage broad emergent themes were identified. Axial coding was undertaken to refine and organise the open codes without detracting from the meaning of the raw data. Finally, the selective coding phase identified deeper thematic patterns (Newman, 2012).

Stance and valence framing were used to gain insight into the media frames being used; that is, the message or story being conveyed. As headlines and articles can be interpreted by different readers in numerous ways, headlines or articles that were ambiguous in their stance or valence were coded to 'neutral', as were headlines that were not directly related to tourism and mining (Bacon, 2011). To determine the prevalence of hedging this research built on the list of hedging words used by Hurlimann and Dolnicar (2012), including: suggest, appear, could, might, tentative, uncertain, most likely, seem, can and may. To identify superlatives, this research drew on the Oxford Dictionary (2013) description of superlatives which suggests that they are formed by adding 'most' before an adjective or ending the adjective in '-est' (such as largest, greatest, richest).

While the coding was interpretative, it was undertaken by two experienced researchers with an inter-coder reliability test being undertaken on every 20 th article (71 variables coded for each article) revealing 94\% consistency between the two coders. Generally an inter-coder reliability percentage of $80 \%$ or higher is considered reliable (Poindexter \& McCombs, 2000). Once the data were coded it was transferred to Stata v.12 for analysis, which included systematically analysing the results using descriptive statistics, as well as chi-square tests to identify and report on significant differences. The chi-square tests were undertaken by crosstabulating arrays of binary coded variables relating to the broadcast area, publisher, theme, valence framing, stance and use of hedging and superlativism. 


\section{Results}

\section{Publisher and regional focus}

There was a large diversity in the publishers releasing articles on tourism and mining, with 107 different online publication outlets (of which 73 published only a single article). This indicates there is a wide range of media covering this topic, with concern for tourism and mining in Australia found at the national (13 media outlets or 83 articles), state (17 media outlets or 65 articles) and local (18 media outlets or 27 articles) level, as well as solely online (62 media outlets or 90 articles). Importantly, while most publishers were of a generic nature (e.g. daily national newspapers), several media outlets specialised in either mining or tourism (e.g. Australian Mining, Transport and Logistics News, eTravel Blackboard, the Australian Mining Review, CoalGuru). As seen in Table 1 the most prominent publisher was the Australian Broadcasting Corporation (ABC).

\section{[TABLE 1 ABOUT HERE]}

A majority of the articles discussed tourism and mining issues from a generic national level perspective (51\%), rather than a localised or place-based one. For example, $61 \%$ of articles that were solely published online and $54 \%$ of the articles published by state level media outlets reported on national level issues. Conversely, $42 \%$ of articles published by national media outlets and $56 \%$ of articles published by local level media outlets reported on localised or place-based issues. Potentially this is due to the fact that newspapers expect greater reader interest by presenting stories of national significance, particularly if they are not regionally based outlets. There were also some discussions at the state level (12\%), particularly in regards to Queensland (7.2\%), South Australia and Western Australia (1.9\% each). The high number of articles related to Queensland may be associated with the state 
election that occurred on 24 March 2012 in which the key economic policy of the Queensland Liberal-National party was on mining, tourism, agriculture and infrastructure. Discussions about regional areas outside capital cities represented $35 \%$ of all articles, with just $2 \%$ discussing capital cities. This is not surprising as mining occurs in regional Australia, whereas political debate about mining is likely to be observed in the cities. The key regional area discussed in regard to tourism and mining was the Hunter Valley in New South Wales (3.8\%), followed by Kalgoorlie-Boulder and Port Hedland in Western Australia (3\% each). The national media outlet $\mathrm{ABC}$ was significantly more likely than other publishers to report on local rather than national issues $\left(\chi^{2}(3)=16.333, \mathrm{p}=0.001\right)$.

\section{Thematic analysis of key issues relating to tourism and mining}

Thematic analysis of key issues arising in the articles provides an indication of issue framing, as the key themes and issues are those topics which are most focused on by the media and therefore likely to be the most influential and salient in people's minds (Scheufele $\&$ Tewksbury, 2007). Nine prominent themes emerged from the 55 key issues that were sourced from the online news articles (Table 2). Generally articles contained a single theme (67\%), although $25 \%$ contained two themes, and $6 \%$ contained three themes, with $2 \%$ containing 4 or 5 themes. Five of the themes dealt directly with the relationship between tourism and mining, with the other four being focused on issues relating to either mining or tourism (with the other industry just being mentioned as an aside). This indicates that an analysis of the complex relationship between two issues requires consideration of salient themes attached to each individual issue. For example, reporting on the social and environmental impacts of mining is of relevance to the discourse on mining and tourism, independent of mining's relationship with tourism. 


\section{[TABLE 2 ABOUT HERE]}

The most prevalent theme focused on the macro-economic impact that mining has on the Australian economy, including its impact on the tourism industry, with 132 articles and 14 of the key issues being associated with this theme. In relation to tourism more specifically, the most prominent issue cited within this theme was the negative impact of the high Australian dollar and an over-reliance on mining that undermines long-term wealth:

... the mining boom has pushed the exchange rate up and up, and around 200,000 international visitors have failed to show up in Cairns. (ABC, Australia's mining boom driving tourists away, 12 March 2012)

Any nation that aspires to have sustainable prosperity should have an economy that is equally reliant on agriculture, manufacturing, professional services, tourism, education, retailing and mining ... To be heavily reliant on one industry is not smart, yet Australia currently places too much reliance on mining. (Online Opinion: Australia's e-journal of social and political debate, Can Australia survive without mining? 19 September 2012)

The range of themes and issues presented in Table 2 are evidence of the prevalence of very diverse media frames, highlighting not only the complexity of the mining-tourism relationship but also the salience of each sector in its own right. In some cases strong language was used and messages were personalised by involving or naming key actors. Importantly, key actors, elites and lobby groups were reported on for both the mining (e.g. Gina Rhinehart, Clive Palmer, Marius Kloppers, Karl Spaleck, the Minerals Council of Australia) and the tourism sector (e.g. Justin Wastnage, Geoff Dixon, Evan Hall, Daniel 
Gschwind, Bruce Tyrrell, John Lee, John Alwyn-Jones, Tourism and Transport Forum, Queensland Tourism Industry Council). For example, illustrating Theme 2, one article stated: 'Tourism mogul Graham Turner will be at Rosewood tomorrow to add weight to the community's growing fight against mining' (The Queensland Times, Tourism mogul Graham Turner in town to battle miners, 18 January 2013). Highlighting the environmental impacts of mining (Theme 4), another article reported:

If Tony Burke thinks he knows better than the Government's original 1981 listing of the Great Barrier Reef World Heritage Area, accepted by the international community, he should explain why he believes Gladstone harbour, right next to the Reef, is no longer worth protecting. (DredgingToday.com, Australia: Greens unhappy with Environment Minister, $6^{\text {th }}$ March 2012)

Political statements, such as 'Stop viewing China like it's the Cold War'(quoting James Packer, a casino business owner in Australia and Macau, 5 November 2012), further adds to the polarisation of the debate, for example in relation to the Asian Century (Theme 5). The quote above is significant and credible given James Packer's prominence as a business leader in Australian tourism.

\section{Valence framing, stance, hedging and superlatives}

To identify valance framing, the headlines and articles were coded by whether they primarily pitched a positive or negative story (regardless of the focus or context). Notably, the majority of the headlines were neutral, while the main body of the articles were generally framed negatively. The articles were also coded by stance to determine whether they were pro-tourism, pro-mining, anti-tourism or anti-mining. The discussion of tourism in the articles was generally positive, with $69 \%$ having a pro-tourism and just $5 \%$ having an anti-tourism 
slant (Table 3). Conversely, the discussion relating to mining was more balanced, with $32 \%$ having a pro-mining and $34 \%$ having an anti-mining slant. The media analysis showed evidence that tourism is becoming more coordinated, providing support for the hypothesis that tourism and mining conflict is becoming an increasingly complex and political problem, as evidenced by the following passage:

Australian tourism operators have declared war on the government, taking the unprecedented move of buying full page advertisements in major newspapers about how rising taxes are making it tougher for tourism ... This is the first time that the tourism industry has joined together to place an ad related to prices ...While mining was in the fast lane in Australia's two speed economy, tourism and manufacturing were struggling ... The budget had a whole lot of help for the car industry and a whole lot of pain for the tourism industry. (News.com.au, Aussie tourism goes to war over new taxes, 14 June 2012)

As seen in Table 3, hedging was observed in 120 articles (45\%). Only Theme 1 (macroeconomic impact of mining on the Australian economy; $\chi^{2}(1)=12.33, p<0.001$ ) and Theme 7 (mining can benefit tourism; $\chi^{2}(1)=4.14, p=0.042$ ) were significantly more likely to hedge. In addition, articles that were anti-mining $\left(\chi^{2}(1)=4.10, p=0.043\right)$ were significantly more likely to hedge than other articles.

\section{[TABLE 3 ABOUT HERE]}

Superlativism was present in $23 \%$ of the articles and was less prevalent than hedging. Only Theme 6 (tourism is a positive force for the Australian economy) articles were significantly $\left(\chi^{2}(1)=4.82, \mathrm{p}=0.028\right)$ more likely to use superlatives. This theme was also 
more likely to be published by Local and State level media outlets $\left(\chi^{2}(4)=12.58, p=0.014\right)$. Examples of superlative statements used in the articles include: '...the world's richest woman (and Australia's wealthiest miner), Gina Rhinehart...' (The Guardian, In Australia's two-speed economy, mining booms but tourism suffers, 23 August 2012, emphasis added) and 'Mackay is among Australia's fastest-growing regions, there's a key tourism drawcard and there is strong demand from the fly-in, fly-out mining sector.' (Daily Mercury, Budget carrier returns to skies, 11 October 2012, emphasis added). The ABC was significantly $\left(\chi^{2}\right.$ $(1)=8.52, p=0.004)$ less likely than other publishers to use superlatives in their articles as the organisation, being government-owned, generally attempts to remain more neutral in its reporting.

\section{Discussion}

This paper has explored how the media in Australia reports on the relationship between tourism and mining, contributing to the literature by providing insight into framing in competitive multi-issue contexts. The thematic analysis presented in this paper suggests that there is a broad range of perspectives, often value-laden or even polarised, relating to the interaction between tourism and mining in Australia. A key theme to emerge from the media analysis was that rapid mining development has changed the economy and impacted on other industries like tourism, partly due to the negative effects of a higher exchange rate (Connolly \& Lewis, 2010). Articles complained that the strong Australian dollar is also hurting mining as well as tourism, agriculture and manufacturing, but a rejoinder to this was:

Listening to the mining industry complaining about the high exchange rate is like listening to a three-year-old complaining about the noise of their own tantrum. (The Australian Financial Review, Miners should pay a premium, 18 September 2012) 
Considering mining-tourism conflict from a tourism perspective, it is important to understand that the tourism product is often built on a region's natural resources. Efforts in tourism management have long focused on the sustainable management of the limited natural resources on which tourism depends (Capó, Font \& Nadel, 2007; McLennan, Pham et al., 2012). Perhaps unsurprisingly then, the tourism industry's concern is primarily focused on the potential for mining to destroy the natural environment on which the tourism product is based, thus there is a critical need to assess the impacts of both sectors (Conesa, 2010). Further, another key tourism industry concern was related to competition with mining for labour. The articles were often framed around a discussion of the mining industry offering less secure, short-term, higher paid jobs, with tourism being promoted as providing more secure, longer-term, but lower paid employment. The key argument taken up in the media in relation to competition for labour was that tourism is a larger employer of Australians.

From a mining perspective, the relationship is portrayed very differently; mining is a sector that has been extremely successful and well supported, and - according to the articles analysed in this research - has little consideration for its interaction with tourism. Instead, tourism appears to represent the 'underdog' with mining being portrayed as the dominant sector. The analysis provided evidence of power supremacy, with mining being represented by strong identifiable leaders such as Gina Rhinehart and Clive Palmer. Perhaps due to this perceived power imbalance, one article reported that tourism is more trusted by Australians than mining due to a perception that the mining industry was less likely to act in the interest of the public. Trust is also identified in the literature as a key issue restricting the coexistence of tourism and mining, often because mining is generally owned by large corporations powerful enough to promote their own agenda, whereas tourism typically consists of a large number of small and medium sized enterprises (Lichrou \& O’Malley, 
2006). Latimer (2013) argues that the trust Australians have for the actions of the mining sector depends to a large extent on their political stance.

Despite mining's current prominence as a key Australian exporter, the tourism sector has retained a strong voice in the contested middle ground of media framing. Thanks to an increasing number of key tourism spokespeople, as well as increasingly well organised lobby groups, tourism seems to have influenced the media system to gain greater positive coverage compared with mining. An 'adversarial frame' was employed in the case of mining more frequently than in tourism with $34 \%$ of articles being anti-mining and just $5 \%$ being antitourism. The articles revealed evidence of supporting tourism over mining with $69 \%$ being pro-tourism and just 32\% being pro-mining. The dominant support for tourism could be a sign of the tourism industry successfully (and directly) influencing the media in their stance of reporting, or it could reflect tourism's positive image in local communities, which the media reflects in their representation of tourism matters.

This research also examined journalistic tools used to represent the conflicts between tourism and mining. This indicates that discussions on the relationship between tourism and mining (i.e. the intersection in Figure 1) is characterised by uncertainty. For example, hedging was observed in $45 \%$ of the articles which is comparably high. An earlier study on water issues in Australian news articles had a 35\% rate of hedging (Hurlimann \& Dolnicar, 2012), while a media analysis on climate change and global warming, which is a highly contentious issue, found half of the articles used hedging and were very likely to confuse the public (Fortner et al., 2000). In this research, articles that were more likely to hedge tended to be articles against mining, with themes relating to the issue that mining imposes flow-on economic impacts on tourism, and that tourism is a positive force for the Australian economy. This suggests that those journalists that chose to represent a tourism advocacy position in their frame building are more likely to use hedging as a technique. 
Schmallegger and Carson (2010) found that the media discourse regarding tourism development is often characterised by superlative expression aimed at promoting development projects. Given mining's status as a key source of economic development in Australia and the prevalence of pro-tourism articles in this research, it is no surprise that superlative statements were present in $23 \%$ of articles. Theme 3 (tourism being a positive force for the Australian economy) articles were particularly more likely to use superlatives, suggesting that the tourism industry tends to overstate its importance when interacting with the media or influencing the broader audience. The high prevalence of hedging and the common use of superlatives, combined with evidence of multiple values and adversarial framing by the media may indicate that the competitive relationship between tourism and mining represents a 'wicked problem'. Wicked problems are characterised by many opinions, values, uncertainty, public interest and a lack of a clear solution to the problem. As a result the problem is often controversial, framed in multiple ways and difficult to solve due to a reluctance to reach a resolution $(\mathrm{Nie}, 2003)$. Research has indicated that conflict between sectors represent wicked problems as the issue is often highly socially constructed and influenced by competitive behaviour (Yaffee, 1997). Examples from the literature report on conflict related to wicked problems relate to mining versus nature conservation (Nie, 2003) and fisheries and coastal governance (Jentoft \& Chuenpagdee, 2009).

This research also found that while tourism and mining issues are often more likely to be local-level problems, they are largely reported through national level media coverage. The literature suggests that wicked problems, particularly those that involve mining, are often characterised by small place-based groups fighting larger corporations impinging on their territory (Nie, 2003). This was clearly the case regarding tourism and mining conflict in Australia, with several articles discussing tourism operators' opposition to the entrance of mining in their region. However, while the literature suggests that the impacts of structural 
change are more prominent at the local level (McLennan, Ruhanen et al., 2012), this analysis found media discussions of tourism and mining issues to favour the macroeconomic level.

The greater prevalence of national-level reporting is an issue if the local viewpoints are not readily apparent in the media as the public may not fully understand the complex challenges associated with fostering co-existence between tourism and mining. This is a critical issue when policies are developed at the national level by leaders who may not be fully in touch with local complexities and thus the policies are at risk of being inappropriate. Consequently, not only is there a need for tourism and mining need to work together more effectively, but the media needs to portray more localised views on the issues.

Lastly, this analysis revealed that a focus on the relationship between tourism and mining alone is insufficient to fully interpret the findings. Media frames are built by media systems, which are influenced by members of the audience who may also work in the media (i.e., journalists). Thus, media systems are also likely to be influenced by commonly held perceptions or social representations of important aspects of Australia's economy or society (Scheufele, 1999). Both tourism and mining have a long deeply engrained history in the Australian identity. Mining has cyclically been the engine of Australia's exports since the early Gold Rush era, while tourism has been marketed based on the Australian outdoor lifestyle and recreational activities available in iconic locations (Tourism Australia, no date). Clearly, when two such important sectors interact to define their 'territory', the resulting representation is likely to be multi-faceted, volatile, and value-laden (Becken, McLennan \& Moyle, 2014). A framing analysis of related media coverage must give justice to the importance of each individual sector, as well as the relationship.

Based on Scheufele (1999), media framing is conceptualised as a continuous cycle between the media and its audience, linked via several key processes. Notably, media systems influence media frames, which in turn influence audience frames and ultimately perceptions 
and behaviour of the public. With journalists also being audiences, the perceptions and behaviour of the public (and the journalist) then also influences the media system and its framing. The present analysis focused on media frames and captured elements of frame building and setting. Extending Scheufele's original model, Figure 1 presents a multi-issue model that integrates two (or more if necessary) framing cycles to competitive contexts, allowing a greater conceptualisation of interacting issues, their framing, and public audience effects. Figure 1 illustrates that the tourism and mining framing processes operate similarly, but independently, overlapping in the outcomes phase resulting in a competitive context arising.

[INSERT FIGURE 1 ABOUT HERE]

\section{Conclusion}

This paper explored the media representation of the current issues between tourism and mining in Australia, with the results suggesting that a wicked problem may be occurring. Due to the cyclical nature of framing, this media analysis provided insight not only into the media systems, but also into the public and policy-makers perceptions of tourism and mining issues. The media analysis revealed polarised and often heated debates within the media, with evidence of biased valence framing, stance and hedging. This tension suggests that the conflict between the two groups represents a difficult, and maybe unsolvable, issue for government policymakers. Furthermore, this conflict may be making it difficult for decision makers to set appropriate policies for the two industries and to overcome issues that exist between them. This highlights a need to explore whether the media's portrayal of a wicked problem between mining and tourism is evident in reality. 
This paper contributes to the growing debate on competitive contexts by delivering a greater understanding of the interaction between tourism and mining. It is a cross-cutting piece of work that integrates two sectors which are commonly researched separately. Previous studies on the co-existence of tourism and mining suggest that there is often conflict due to their dependence on similar resources and the impacts that each has on an economy (Ironside, 2000; Hughes, 2012). While tourism and mining are two prominent industries in Australia, this paper found evidence that there is significant disassociation between the tourism and mining industries, with high pro-tourism and anti-mining discourse amongst the articles. There is a need to replicate the current study using other time periods or within a different geographic context for comparative purposes. Future research should also seek to investigate whether there are variations according to location/context, commodity, and company structure to provide a broader perspective on the conflict. Importantly, as there is evidence that the competitive context between tourism and mining is resulting in confusion amongst the Australian public and policy-makers, there is a critical need for policy research relating to the co-existence of tourism and mining. 


\section{References}

Australian Bureau of Statistics. (2012). Year Book Australia, 2012. Cat. 1301.0 Retrieved 7th February, 2013, from

http://www.abs.gov.au/ausstats/abs@.nsf/Lookup/by\%20Subject/1301.0 2012 Main $\% 20$ Features $\sim$ Mining\%20Industry 150

Bacon, W. (2011). A Sceptical Climate: Media coverage of climate change in Australia 2011.

Part 1 - Climate change policy. Sydney: University of Technology.

Ballesteros, E. R., \& Ramírez, M. H. (2007). Identity and community - Reflections on the development of mining heritage tourism in Southern Spain. Tourism Management, 28(3), 677-687.

Baran, S. J., \& Davis, D. K. (2009). Mass Communication Theory: Foundations, Ferment and Future $\left(5^{\text {th }}\right.$ ed.). Boston, MA: Wadsworth Cengage Learning.

Battellino, R. (2010). Mining Booms and the Australian Economy. Bulletin (pp. 63-69). Sydney: Reserve Bank of Australia.

Becken, S. McLennan, C. \& Moyle, B. (2014). World Heritage Area at Risk? Resident and Stakeholder Perceptions of the Great Barrier Reef in Gladstone, Australia. Griffith Institute for Tourism Research Report No. 2. Gold Coast: Griffith University.

Bengston, D. N., \& Fan, D. P. (1999). Conflict over natural resource management: A social indicator based on analysis of online news media text. Society \& Natural Resources: An International Journal, 12(5), 493-500.

Borah, P. (2011). Conceptual issues in framing theory: A systematic examination of a decade's literature. Journal of Communication, 61, 246-263.

Brewer, P. R., Graf, J., \& Willnat, L. (2003). Priming or Framing Media Influence on Attitudes Toward Foreign Countries. Gazette, 65(6), 493-508.

Buultjens, J., Brereton, D., Memmott, P., Reser, J., Thomson, L., \& O’Rourke, T. (2010). The mining sector and indigenous tourism development in Weipa, Queensland. Tourism Management, 31(5), 597-606. 
Capó, J., Font, A. R., \& Nadel, J. R. (2007). Dutch Disease in Tourism Economies: Evidence from the Balearics and the Canary Islands. Journal of Sustainable Tourism, 15(6), 615-627.

Carson, D., Schmallegger, D., \& Harwood, S. (2010). A City for the temporary? Political economy and urban planning in Darwin, Australia. Urban Policy and Research, 28(3), 293-310.

Champion, D., \& Chapman, S. (2005). Framing pub smoking bans: an analysis of Australian print news media coverage, March 1996-March 2003. Journal of Epidemiol Community Health, 59, 679-684.

Chong, D., \& Druckman, J. N. (2007). Framing theory. Annual Review of Political Science, $10,103-126$.

Cleary, P. (2011). Too much luck: The mining boom and Australia's future. Melbourne: Black Inc.

Conesa, H. M. (2010). The difficulties in the development of mining tourism projects: the case of La Unión Mining District (SE Spain). Pasos: Revista de turismo y patrimonio cultural, 8(4), 653-660.

Connolly, E., \& Lewis, C. (2010). Structural Change in the Australian Economy Bulletin. Sydney: Reserve Bank of Australia.

Dispensa, J. M., \& Brulle, R. J. (2003). Media's social construction of environmental issues: focus on global warming - a comparative study. International Journal of Sociology and Social Policy, 23(10), 74-105.

Druckman, J. N. (2001). The implications of framing effects for citizen competence. Political Behavior, 23(3), 225-256.

Druckman, J. N. (2004). Political preference formation: Competition, deliberation and the (ir)relevance of framing effects. American Political Science Review, 98(4), 671-686. 
Entman, R. M. (1993). Framing: Toward clarification of a fractured paradigm. Journal of Communication, 43(4), 51-58.

Entman, R. M. (2010). Media framing biases and political power: Explaining slant in news of Campaign 2008. Journalism, 11(4), 289-408.

Forsyth, P., Dwyer, L. \& Spurr, R. (2014). Is Australian tourism suffering Dutch Disease? Annals of Tourism Research, 46, 1-15.

Fortner, R. W., Lee, J.-Y., Corney, J. R., Romanello, S., Bonnell, J., Luthy, B., . . Ntsiko, N. (2000). Public understanding of climate change: certainty and willingness to act. Environmental Education Research, 6(2), 127-141.

Gamson, W. A., \& Modigliani, A. (1989). Media discourse and public opinion on nuclear power: A constructionist approach. American Journal of Sociology, 95(1), 1-37.

Gans, J. S., \& Leigh, A. (2012). How Partisan is the Press? Multiple Measures of Media Slant. Economic Record, 88(280), 127-147.

Goffman, E. (1974). Frame analysis: An essay on the organization of experience. Cambridge, MA: Harvard University Press.

Gray, B. (2003). Framing of environmental disputes. In R. Lewicki, B. Gray \& M. Elliott (Eds.), Making Sense of Intractable Environmental Conflicts: Concepts and Cases (pp. 11-34). Washington, DC: Island Press.

Haalboom, B. (2012). The intersection of corporate social responsibility guidelines and indigenous rights: Examining neoliberal governance of a proposed mining project in Suriname. Geoforum, 43(5), 969-979.

Huang, G. (2008). Mining and Tourism: Comparing Spatial Patterns, Socioeconomic Contributions, and Environmental Impacts in China. Unpublished PhD Thesis, The University of Vermont. 
Hughes, M. (2012, 6-9 February). Tourism and the mining boom: Golden age, or golden shower? Paper presented at the $22^{\text {nd }}$ Annual Conference of the Council of Australasian Universities in Tourism and Hospitality Education (CAUTHE), Melbourne, VIC.

Hughes, S. (2003). A Gazetteer of Newspapers from the Central Victorian Goldfields (18511901) Johnstone Centre Report No. 198. Albury: The Johnstone Centre, Charles Sturt University.

Hurlimann, A., \& Dolnicar, S. (2012). Newspaper coverage of water issues in Australia. Water Research, 46, 6497-6507.

Ironside, R. G. (2000). Canadian northern settlements: top-down and bottom-up influences. Geografiska Annaler. Series B, Human Geography, 82(2), 103-114.

Jentoft, S. \& Chuenpagdee, R. (2009). Fisheries and coastal governance as a wicked problem. Marine Policy 33, 553-560.

Jönsson, A. M. (2011). Framing environmental risks in the Baltic Sea: A news media analysis. Ambio, 40(2), 121-132.

Karlberg, M. (1997). News and conflict: How adversarial news frames limit public understanding of environmental issues. Alternatives Journal, 23(1), 22-27.

Latimer, C. (2013, 23rd of January). Miners more trusted than the media, Australian Mining. Retrieved from http://www.miningaustralia.com.au/news/miners-more-trusted-thanthe-media

Leatherman, J. C., \& Marcouiller, D. W. (1996). Persistent poverty and natural resource dependence: rural development policy analysis that incorporates income distribution. Journal of Regional Analysis and Policy, 26, 73-94.

Lebert, M. (2008). From the Print Media to the Internet. Project Gutenberg Retrieved 13th February, 2013, from http://www.gutenberg.org/cache/epub/27030/pg27030.html 
Lichrou, M., \& O'Malley, L. (2006). Mining and tourism: Conflicts in the marketing of Milos Island as a tourism destination. Tourism and Hospitality Planning and Development, $3(1), 35-46$.

Maddison, J., \& Watts, R. (2011). The technological fix as a frame in media debates about tailpipe emissions. Technology in Society, 33(3-4), 294-303.

Markey, S., Halseth, G., \& Manson, D. (2008). Challenging the inevitability of rural decline: Advancing the policy of place in northern British Columbia. Journal of Rural Studies, 24(4), 409-421.

McLennan, C., Pham, T. D., Ruhanen, L., Ritchie, B. W., \& Moyle, B. (2012). Counterfactual scenario planning for long-range sustainable local-level tourism transformation. Journal of Sustainable Tourism, 20(6), 801-822.

McLennan, C., Ruhanen, L., Ritchie, B., \& Pham, T. (2012). Dynamics of Destination Development: Investigating the application of Transformation Theory. Journal of Hospitality and Tourism Research, 36(2), 164-190.

Measham, T. G., McKenzie, F. H., Moffat, K., \& Franks, D. M. (2013). An expanded role for the mining sector in Australian society? Rural Society, 22(2), 184-196.

Miranda, M., Burris, P., Bingcang, J., Shearman, P., Briones, J. O., Vina, A. L., \& Menard, S. (2003). Mining and Critical Ecosystems: Mapping the Risks. Washington DC: World Resources Institute.

Morrison, E. (1980). Victorian country newspapers in 1888: William Hine's Rupanyup Spectator and James Ryan's Maffra Spectator. Bulletin: Australia 1888 (pp. 37-51).

Moyle, B., McLennan, C., Becken, S., \& Brown, R. (2014). Learning to play nice: Conflict, synergy and strategies for co-existence between tourism and the resource sector. Paper presented at the $24^{\text {th }}$ Annual Conference of the Council of Australasian Universities in Tourism and Hospitality Education (CAUTHE), Brisbane, Australia. 
Myers, G. (1989). The pragmatics of politeness in scientific articles. Applied Linguistics, $10(1), 1-35$.

Newman, D. S. (2012). A Grounded Theory Study of Supervision of Preservice Consultation Training. Journal of Educational and Psychological Consultation, 22(4), 247-279.

Nie, M. (2003). Drivers of natural resource-based political conflict. Policy sciences, 36(3-4), 307-341.

Nowak, J.-J., \& Sahli, M. (2007). Coastal tourism and 'Dutch disease' in a small economy. Tourism Economics, 13(1), 49-65.

Oxford Dictionary. (2013). Superlative. Retrieved 11th February, 2013, from http://oxforddictionaries.com/definition/english/superlative

Pan, S., Tsai, H., \& Lee, J. (2011). Framing New Zealand: understanding tourism TV commercials. Tourism Management, 32(3), 596-603.

Peck, J. (2013). Polanyi in the Pilbara. Australian Geographer, 44(3), 243-264.

Poindexter, P., \& McCombs, M. (2000). Research in Mass Communication: A Practical Guide. Boston: St Martins.

Prior, T., Giurco, D., Mudd, G., Mason, L., \& Behrisch, J. (2012). Resource depletion, peak minerals and the implications for sustainable resource management. Global Environmental Change, 22(3), 577-587.

Richardson, D. \& Denniss, R. (2011). Mining the Truth: The rhetoric and reality of the commodities boom. The Australia Institute. Available (27/05/14) http://www.tai.org.au/node/1777

Ruhanen, L., McLennan, C., \& Moyle, B. (2013). Strategic issues in the Australian tourism industry: a ten year analysis of national level strategies and plans. Asia Pacific Journal of Tourism Research, 18(3), 220-240. 
Scheufele, D. A. (1999). Framing as a Theory of Media Effects. Journal of Communication, 49, 103-122.

Scheufele, D. A., \& Tewksbury, D. (2007). Framing, Agenda Setting, and Priming: The Evolution of Three Media Effects Models. Journal of Communication, 57, 9-20.

Schmallegger, D., \& Carson, D. (2010). Whose tourism city is it? The role of government in tourism in Darwin, Northern Territory. Tourism and Hospitality Planning and Development, 7(2), 111-129.

Schultz, F., Kleinnijenhuis, J., Oegema, D., Utz, S., \& van Atteveldt, W. (2012). Strategic framing in the BP crisis: A semantic network analysis of associative frames. Public Relations Review, 38, 97-107.

Sniderman, P. M., \& Theriault, S. M. (2004). The structure of political argument and the logic of issue framing. In W. E. Saris \& P. M. Sniderman (Eds.), Studies in public opinion: Attitudes, nonattitudes, measurement error and change (pp. 133-165). Princeton, NJ: Princeton University Press.

Stone, D. (1989). Casual stories and the formation of policy agendas. Political Science Quarterly, 104, 281-300.

Tonts, M., Plummer, P., \& Lawrie, M. (2012). Socio-economic wellbeing in Australian mining towns: A comparative analysis. Journal of Rural Studies, 28(3), 288-301.

Wallis, P., \& Nerlich, B. (2005). Disease metaphors in new epidemics: the UK media framing of the 2003 SARS epidemic. Social Science \& Medicine, 60(11), 2629-2639.

Tourism Australia (no date). Brand Australia. Our Brand Positioning, Proposition and Personality. Available at (27/05/14) http://www.tourism.australia.com/aboutus/brand-australia.aspx

Tourism Research Australia. (2013). The economic impact of the current mining boom on the Australian tourism industry. Canberra: Australian Government. 
Wergin, C., \& Muecke, S. (2012). Questions of value: tourism and the resources boom. Australian Humanities Review, 53(November). Retrieved 19th November, 2013, from http://www.australianhumanitiesreview.org/archive/Issue-November2012/wergin\&muecke.html

Wilson, G. (2010). Multifunctional ‘quality’ and rural community resilience. Transactions of the Institute of British Geographers, 35(3), 364-381.

Wilson, J., \& Becken, S. (2011). Perceived deficiencies in the provision of climate and weather information for tourism: A New Zealand media analysis. New Zealand Geographer, 67, 148-160.

Yaffee, S. L. (1997). Why environmental policy nightmares recur. Conservation Biology, 11(2), 328-337.

Zhu, Y., \& McKenna, B. (2012). Legitimating a Chinese takeover of an Australian iconic firm: Revisiting models of media discourse of legitimacy. Discourse \& Society, 23(5), $525-552$. 
Table 1. Publisher of the articles

\begin{tabular}{|c|c|c|c|c|c|c|c|}
\hline Published by & $\begin{array}{l}\text { No. of } \\
\text { Articles } \\
\end{array}$ & Percent & Type & Format & Availability & Owner & $\begin{array}{l}\text { Political Alignment / } \\
\text { Media Slant }^{1}\end{array}$ \\
\hline $\begin{array}{l}\text { Australian } \\
\text { Broadcasting } \\
\text { Corporation (ABC) }\end{array}$ & 39 & $14.7 \%$ & $\begin{array}{l}\text { Broadcast } \\
\text { television/radio, online, } \\
\text { streaming media }\end{array}$ & $\begin{array}{l}\text { Television/radio, } \\
\text { Online }\end{array}$ & Nationwide & Australian Government & $\begin{array}{l}\text { Government-owned } \\
\text { (accused of bias towards } \\
\text { both liberal \& } \\
\text { conservative views) }\end{array}$ \\
\hline $\begin{array}{l}\text { Sydney Morning } \\
\text { Herald }\end{array}$ & 23 & $8.7 \%$ & $\begin{array}{l}\text { Daily newspaper \& } \\
\text { online }\end{array}$ & $\begin{array}{l}\text { Compact \& } \\
\text { Broadsheet }\end{array}$ & $\begin{array}{l}\text { NSW, Canberra \& } \\
\text { South East Qld, Online }\end{array}$ & Fairfax media & $\begin{array}{l}\text { Pro-labour (Media Slant } \\
=0.462 \text { ) }\end{array}$ \\
\hline The Australian & 12 & $4.5 \%$ & $\begin{array}{l}\text { Daily newspaper \& } \\
\text { online }\end{array}$ & $\begin{array}{l}\text { Broadsheet, Online, } \\
\text { App }\end{array}$ & Nationwide & News limited & $\begin{array}{l}\text { Pro-Coalition (Media } \\
\text { Slant }=0.485)\end{array}$ \\
\hline The Courier-Mail & 11 & $4.2 \%$ & $\begin{array}{l}\text { Daily newspaper \& } \\
\text { online }\end{array}$ & Tabloid & $\begin{array}{l}\text { Qld, most regions of } \\
\text { Northern NSW \& parts } \\
\text { of the NT }\end{array}$ & News limited & $\begin{array}{l}\text { Pro-Coalition (Media } \\
\text { Slant }=0.493 \text { ) }\end{array}$ \\
\hline Australian Mining & 8 & $3.0 \%$ & Magazine \& online & Online, Magazine & Nationwide & Cirrus Media & Mining focused \\
\hline $\begin{array}{l}\text { Australian } \\
\text { Financial Review }\end{array}$ & 8 & $3.0 \%$ & $\begin{array}{l}\text { Daily newspaper \& } \\
\text { online }\end{array}$ & Compact & Nationwide & Fairfax media & $\begin{array}{l}\text { Pro-labour (Media Slant } \\
=0.436 \text { ) }\end{array}$ \\
\hline Herald Sun & 8 & $3.0 \%$ & $\begin{array}{l}\text { Daily newspaper \& } \\
\text { online }\end{array}$ & Tabloid & $\begin{array}{l}\text { VIC, TAS, ACT \& } \\
\text { border regions of SA \& } \\
\text { NSW }\end{array}$ & News Corporation & $\begin{array}{l}\text { Pro-labour (Media Slant } \\
=0.466)\end{array}$ \\
\hline AAP & 6 & $2.3 \%$ & $\begin{array}{l}\text { Breaking news \& } \\
\text { newswire }\end{array}$ & Online & Nationwide & $\begin{array}{l}\text { Fairfax \& News Ltd } \\
\text { (45\% each), West } \\
\text { Australian Newspapers } \\
(8 \%) \& \text { Rural Press }(2 \%)\end{array}$ & Not available \\
\hline News.com.au & 6 & $2.3 \%$ & Online & Online & Nationwide & News Corporation & Not available \\
\hline Canberra Times & 5 & $1.9 \%$ & $\begin{array}{l}\text { Daily newspaper \& } \\
\text { online }\end{array}$ & Broadsheet, Online & Canberra & Fairfax media & $\begin{array}{l}\text { Pro-labour (Media Slant } \\
=0.461 \text { ) }\end{array}$ \\
\hline The Age & 5 & $1.9 \%$ & $\begin{array}{l}\text { Daily newspaper \& } \\
\text { online }\end{array}$ & $\begin{array}{l}\text { Berliner, Compact, } \\
\text { Online }\end{array}$ & $\begin{array}{l}\text { VIC, TAS, ACT \& } \\
\text { border regions of SA \& } \\
\text { NSW }\end{array}$ & Fairfax media & $\begin{array}{l}\text { Pro-labour (Media Slant } \\
=0.466)\end{array}$ \\
\hline The Conversation & 5 & $1.9 \%$ & Online & Online & Nationwide & The Conversation Trust & Academic (Independent) \\
\hline Other sources $^{2}$ & 129 & $48.7 \%$ & & & & & \\
\hline
\end{tabular}

ACT: Australian Capital Territory; NSW: New South Wales; NT: Northern Territory; Qld: Queensland; SA: South Australia; VIC: Victoria

1. Media Slant is a measure for political bias where 0.47 is equality, larger numbers are pro-coalition and smaller numbers are pro-labour (Gans \& Leigh, 2012).

2. Sourced from a variety of online news media that had published less than five articles during the in-scope period. 
Table 2. Themes discussed in the articles

\begin{tabular}{|c|c|c|c|}
\hline Theme & $\begin{array}{l}\text { No. of } \\
\text { articles }\end{array}$ & $\begin{array}{l}\text { No. of } \\
\text { key } \\
\text { issues }\end{array}$ & Exemplar key issues \\
\hline $\begin{array}{l}\text { Theme 1: } \\
\text { Macroeconomic } \\
\text { impact of mining } \\
\text { on the Australian } \\
\text { economy }\end{array}$ & 132 & 14 & $\begin{array}{l}\text { - Mining impacting tourism via high dollar } \\
\text { - Mining exposes Australia's economy to volatile commodity } \\
\text { prices } \\
\text { - Two-speed economy/differences by states } \\
\text { - Mining has created significant structural adjustment in the } \\
\text { economy away from tourism, agriculture, manufacturing } \\
\text { - Mining towns/states are booming while tourist towns/states are } \\
\text { suffering }\end{array}$ \\
\hline $\begin{array}{l}\text { Theme 2: Mining } \\
\text { and tourism } \\
\text { existing together } \\
\text { (positively or } \\
\text { negatively) }\end{array}$ & 91 & 8 & $\begin{array}{l}\text { - Mining makes regions too expensive for locals and tourists - } \\
\text { tourist product in Australia not top-end } \\
\text { - Mining can destroy tourism products } \\
\text { - Conflict between mining and tourism } \\
\text { - Tourism impacted by visitors' poor perceptions of mining } \\
\text { - Mining sites can be turned into tourism products }\end{array}$ \\
\hline $\begin{array}{l}\text { Theme 3: Mining } \\
\text { and tourism } \\
\text { compete for labour } \\
\text { and resources }\end{array}$ & 38 & 10 & $\begin{array}{l}\text { - Mining creates jobs } \\
\text { - Mining increases competition for labour } \\
\text { - Mining drops staff quickly during downturn/only employs } 1 \% \\
\text { of workers / tourism is a bigger, more stable employer } \\
\text { - Wage structures need to take into account two-speed economy } \\
\text { - Mining ruining infrastructure used by tourism (i.e. roads) } \\
\text { - Flights into mining towns expensive }\end{array}$ \\
\hline $\begin{array}{l}\text { Theme4: Mining } \\
\text { has environmental } \\
\text { and social } \\
\text { consequences }\end{array}$ & 35 & 4 & $\begin{array}{l}\text { - Protecting tourism product from mining/tourism lobbying } \\
\text { against mining } \\
\text { - Mining benefits a few very rich } \\
\text { - Mining has negative impact on environment/community }\end{array}$ \\
\hline $\begin{array}{l}\text { Theme 5: Asian } \\
\text { Century }\end{array}$ & 28 & 4 & $\begin{array}{l}\text { - Mining and tourism are/will benefit from China } \\
\text { - Need to look to tourism, education and agriculture after mining } \\
\text { - Need to equip tourism industry to cater for Asian tourist }\end{array}$ \\
\hline $\begin{array}{l}\text { Theme 6: Tourism } \\
\text { is a positive force } \\
\text { for the Australian } \\
\text { economy }\end{array}$ & 21 & 6 & $\begin{array}{l}\text { - Tourism is a long-term industry while mining is short-term } \\
\text { - Tourism can replace mining } \\
\text { - Mining and tourism benefits indigenous people } \\
\text { - Tourism protects the environment } \\
\text { - Tourism more trusted than mining }\end{array}$ \\
\hline $\begin{array}{l}\text { Theme } 7 \text { : Mining } \\
\text { can benefit tourism }\end{array}$ & 18 & 3 & $\begin{array}{l}\text { - Mining funding tourism investment/product } \\
\text { development/creates tourism opportunities } \\
\text { - Miners can be a key tourism market }\end{array}$ \\
\hline $\begin{array}{l}\text { Theme 8: } \\
\text { Externalities }\end{array}$ & 10 & 3 & $\begin{array}{l}\text { - Collapse of airline will not impact tourism or mining } \\
\text { - Natural disasters have impacted tourism and mining } \\
\text { - New infrastructure/air services/accommodation benefits mining } \\
\text { and tourism }\end{array}$ \\
\hline $\begin{array}{l}\text { Theme 9: Mining is } \\
\text { a positive force for } \\
\text { the Australian } \\
\text { economy }\end{array}$ & 5 & 3 & $\begin{array}{l}\text { - Mining can establish hospitals, doctors and jobs in regional } \\
\text { areas } \\
\text { - Pro-mining lobbying }\end{array}$ \\
\hline
\end{tabular}


Table 3. Valence framing, stance, hedging and superlatives in the articles

\begin{tabular}{|c|c|c|c|}
\hline Valence Framing & $\begin{array}{l}\text { Number of } \\
\text { articles }\end{array}$ & Per cent & Exemplar Quote \\
\hline Positive headline & 62 & $23 \%$ & 'Australia still a traveller's aspiration: TTF' - Travel News Your Way: Asia Edition, 7 November 2012 \\
\hline Negative headline & 44 & $17 \%$ & 'Too many cooks in the mining kitchen' - The Global Mail, 6 February 2012 \\
\hline Neutral headline & 174 & $66 \%$ & 'Australia in the Asian Century' - Asia Sentinel, 20 October 2012 \\
\hline Positive story & 105 & $40 \%$ & $\begin{array}{l}\text { 'Amid the gloom of some economic news and media focus on the resources boom, three industries have grown substantially in } \\
\text { the past year - agriculture, tourism and health services' - Hotspotting.com.au, It's not all about mining: tourism, farming and } \\
\text { healthcare are all thriving, } 18 \text { May } 2012\end{array}$ \\
\hline Negative story & 131 & $49 \%$ & $\begin{array}{l}\text { '... research shows mining is driving the dollar higher and deterring tourists from travelling to Australia.' }-\mathrm{ABC} \text {, Australia's } \\
\text { mining boom driving tourists away, } 12 \text { March } 2012\end{array}$ \\
\hline Neutral story & 29 & $11 \%$ & $\begin{array}{l}\text { 'Mining magnate Clive Palmer bragged about his life size replica dinosaur being an attraction at the prestigious PGA } \\
\text { Championships Golf event on the same day a Sunshine Coast councillor voiced concerns about the billionaire's 'tacky' plans.' - } \\
\text { Brisbane Times, Council threatens dinosaur extinction, } 22 \text { November } 2012\end{array}$ \\
\hline Stance & $\begin{array}{l}\text { Number of } \\
\text { articles }\end{array}$ & Per cent & Exemplar Quote \\
\hline Pro-tourism & 183 & $69 \%$ & $\begin{array}{l}\text { 'China's appetite for mining related investments in Australia may be dwindling, but its appetite for Australian scenic spots has } \\
\text { helped the resource-rich nation post a record number of tourist arrivals in August.' - IBTraveler, This time, China helps boost } \\
\text { Australia's tourism, } 9 \text { October } 2012\end{array}$ \\
\hline Pro-mining & 84 & $32 \%$ & 'The resources boom is driving the economy' - The Sydney Morning Herald, The pits, and we love it, 12 October 2012 \\
\hline Anti-tourism & 13 & $5 \%$ & $\begin{array}{l}\text { '... a decline in tourism activity is allowing the mining industry to flourish. [DEIDENTIFIED] says the tourism industry is } \\
\text { almost running at a deficit... it was inevitable some industries would shrink in size as workers flocked to the burgeoning mining } \\
\text { sector.' - ABC, Forum hears tourism woes helping mine industry, } 13 \text { September } 2012\end{array}$ \\
\hline Anti-mining & 91 & $34 \%$ & $\begin{array}{l}\text { 'Queensland's caravan and camping industry say the mining boom is proving a serious threat to rural tourism.' - ABC, Fears } \\
\text { mining boom limits caravan tourism, } 17 \text { October } 2012\end{array}$ \\
\hline $\begin{array}{l}\text { Pro-tourism \& Pro- } \\
\text { mining }\end{array}$ & 73 & $28 \%$ & $\begin{array}{l}\text { 'The mining town of Port Hedland in Western Australia's mineral rich Pilbara has ambitions to become a leading destination for } \\
\text { cruise ship tours.' - Mining.com, Iron ore port to become popular cruise tour destination, } 8 \text { November } 2012\end{array}$ \\
\hline $\begin{array}{l}\text { Anti-tourism \& } \\
\text { Anti-mining }\end{array}$ & 5 & $2 \%$ & $\begin{array}{l}\text { 'With glitzy production values, and a script that omits the word "gambling", the ads are reminiscent of the anti-mining-tax } \\
\text { campaign run by the resources sector, another industry that must contend with NIMBY-ism and a poor public image... High } \\
\text { rollers from the Chinese market tend to go inside and stay there... They don't engage, and don't have a broader impact on the } \\
\text { local economy. That sort of tourism does not bring long-term, sustainable benefits.' - The Global Mail, Empire Under the Sun, } \\
15 \text { January } 2013\end{array}$ \\
\hline Mixed stance ${ }^{1}$ & 140 & $53 \%$ & $\begin{array}{l}\text { 'Premier Campbell Newman is hoping growth in the construction and tourism sectors will offset the potential loss of } 1,000 \text { coal } \\
\text { mining jobs this year' - ABC, Number of new building jobs still uncertain, } 22 \text { January } 2013\end{array}$ \\
\hline No stance & 51 & $19 \%$ & $\begin{array}{l}\text { 'The principal industry is phosphate mining, with a smaller slice of the economy supported by tourism.' - Postmedia News, } \\
\text { Australia's asylum-seekers find nothing but misery on Christmas Island, } 18 \text { November } 2012\end{array}$ \\
\hline
\end{tabular}




\begin{tabular}{|c|c|c|c|}
\hline Hedging & $\begin{array}{l}\text { Number of } \\
\text { articles }\end{array}$ & Per cent & Exemplar Quote (emphasis added) \\
\hline No Hedging Words & 145 & $55 \%$ & $\begin{array}{l}\text { 'If Australians need a prod to think more broadly about the opportunities Asia presents, a sharp one has come with the claim } \\
\text { that the new tax on mining super profits yielded no revenue in its initial quarter because of falling commodity prices.' - The } \\
\text { Sydney Morning Herald, Asian future isn 't just about mining, } 28 \text { October } 2012\end{array}$ \\
\hline 1 hedging word & 71 & $27 \%$ & $\begin{array}{l}\text { 'This escalating level of protests and local conflicts suggests that the public debate over the value of mining has not reached a } \\
\text { consensus' - The Conversation, Mining and the environment: the future of Australia's brand, } 11 \text { July } 2012\end{array}$ \\
\hline 2 hedging words & 35 & $13 \%$ & $\begin{array}{l}\text { 'Because the boom is based on Asian demand, it will endure and could be much wider than just minerals, if we do things } \\
\text { correctly. As Asian incomes rise, agriculture, education and tourism can also benefit and the more flexible our economy is, the } \\
\text { more likely it is that we can take advantage.' - The Australian, Mining boom can lift whole economy, } 14 \text { March } 2012\end{array}$ \\
\hline $\begin{array}{l}3 \text { or more hedging } \\
\text { words }\end{array}$ & 14 & $5 \%$ & $\begin{array}{l}\text { 'While it might seem obvious that the next step would be to look for beaten down retailers and tourism shares, some sceptical } \\
\text { thinking may be in order here' - Thebull.com.au, What a China slowdown means for Aussie stocks, } 23 \text { January } 2013\end{array}$ \\
\hline Superlativism & $\begin{array}{l}\text { Number of } \\
\text { articles }\end{array}$ & Per cent & Exemplar Quote (emphasis added) \\
\hline $\begin{array}{l}\text { Superlative words } \\
\text { present }\end{array}$ & 62 & $23 \%$ & $\begin{array}{l}\text { 'How could Australia's trade performance be so lacklustre in the middle of our largest ever mining boom?' - Canberra Times, } \\
\text { Selling out our country, } 15 \text { September } 2012\end{array}$ \\
\hline
\end{tabular}


Figure 1. Media framing processes under the competitive context of tourism and mining 